\title{
抗炎症薬（フルチカゾン吸入，プランルカスト）の 小児気管支喘息患者気道過敏性に対する効果
}

\author{
岡畠宏易 ${ }^{1)}$ 辻徹 郎 ${ }^{1,2)}$ 大 黒一 成 ${ }^{1)}$ \\ 国立大竹病院小児科（現 独立行政法人国立病院機構大竹病院小児科）11 \\ 現 JA尾道総合病院小览科 ${ }^{2}$
}

key words : フルチカゾン, プランルカスト，小児気管支喘息，気道過敏性，メサコリン

抄 録

国立大竹病院小児科受診中のフルチカゾン吸入（22名）ないしプランルカスト（14名）治療開始時に軽症持続 型ないし中等症持続型の小児気管支喘息患者（7-15歳）で，テオフィリン徐放薬も併用しつつ，6か月以上治療後， 5 か月以上継続して喘息日誌上発作をみとめなくなった児を対象とし, 治療開始前と発作抑制後の 2 回, メサコリ ンを用いて, 気道過敏性閾值の推移を検討した。治療開始前, 発作抑制後の䦨值の幾何平均は, フルチカゾン吸 入で, 前 $243.5 \mu \mathrm{g} / \mathrm{mL}$, 後 $2074.6 \mu \mathrm{g} / \mathrm{mL}$, プランルカストで, 前 $238.1 \mu \mathrm{g} / \mathrm{mL}$, 後 $862.7 \mu \mathrm{g} / \mathrm{mL}$ で両者とも有意 の改善をみた.フルチカゾン吸入の児では，22名中 13 名が治療前後で 8 倍以上の閾值濃度の改善をみたのに対し， プランルカスト投与では 14 名中 3 名にみとめたのみで，フルチカゾン吸入児に，より改善傾向をみ（ $=0.0611 ）$, 治療開始前の閾值の $196 \mu \mathrm{g} / \mathrm{mL}$ 以下の坚 19 名の検討では両治療間に有意の差を観察した（ $\mathrm{p}=0.0238 ）$. 喘息日誌 上発作がほぼ同期間抑制されている児の間でも，使用抗炎症薬により気道過敏性に差をみることが示唆された.

緒言

近年，ガイドラインを中心とした気管支喘息（以下， 喘息と略す）治療法の普及，とりわけ小児気管支喘息 治療管理ガイドライン $2002^{1)}$ で，6歳以上の軽症持続 型以上の児でも長期管理薬としてその使用が取り上げ られている, ステロイド吸入薬やロイコトリエン拮抗 薬のような薬剤の普及から, 喘息罹患児の発作予防や 肺機能の改善が十分になされる例が増加してきた。 今 回我々は，これらの薬剤の中で，ステロイド吸入薬の フルチカゾン（以下フルチカゾン吸入）と, ロイコト リエン拮抗薬のプランルカストの, 小児喘息患者の気 道過敏性に対する効果を検討したので報告する.

Abbreviation : PC20 ; provocative concentration of methacholine causing a $20 \%$ fall in $\mathrm{FEV}_{1.0}$, PD20 ; provocative dose of methacholine causing a $20 \%$ fall in $\mathrm{FEV}_{1.0}$

\section{対象および方法}

\section{（検討 1）}

対象は, 平成13-15 年に当科受診中の軽症持続型, 中等症持続型の喘息罹患児 (7-15歳) の内, 抗炎症薬 として, ステロイド吸入薬のフルチカゾン吸入か, 口 イコトリエン拮抗薬のプランルカストを用いて治療を 6か月以上おこなった者で, 喘息日誌上少なくとも5か 月以上継続して喘息発作の記載のない児, 合計 36 名

(フルチカゾン吸入使用児 22 名, プランルカスト使用 児 14 名）とした。フルチカゾン吸入の吸入量は 2.88$6.39 \mu \mathrm{g} / \mathrm{kg} /$ 日 $(50 \mu \mathrm{g} /$ 日 1 名, $100 \mu \mathrm{g} /$ 日9名, $150 \mu \mathrm{g} /$ 日 2 名, $200 \mu \mathrm{g} /$ 日 10 名), プランルカスト使用量は $7 \mathrm{mg} / \mathrm{kg} /$ 日であった. 対象児のフルチカゾン吸入, プ ランルカスト以外の, 頓用薬を除いた, 定期的併用薬 としては, テオフィリン徐放薬のみを全例に用い, 検 討期間終了まで, 原則としてその使用を継続した.

今回検討の薬剤の使用は, 保護者及び本人への各薬 剂の有効性と副作用についての説明後, その選択を尊 重し,オープントライアルとして治療を開始した。尚, 
今回の検討期間ではフルチカゾン吸入で 8 名, プラン ルカストで 20 名が喘息発作の抑制が十分でなく, 脱落 例となり, 前述の検討対象とはならなかった。

気道過敏性の検討は，その治療開始時（少なくとも 発作時の治療で， 3 週間以上発作が見られなくなった 時点）と治療継続中の治療開始後約 6か月目（5.5-7.5 か月目）の 2 回行い，その過敏性閥值を比較した.

対象児の背景では, 表 1 に示すごとく, 対象児の年 齢で，プランルカスト使用児が，フルチカゾン吸入の 児に比較して低年齢である傾向がみられた。

\section{（検討 2）}

次に, 対象の治療開始前の過敏性閾值の高低により 検討薬剂の効果に差があるかどうかを検討のため，今 回の対象児を約半数ずつに分けうる治療開始時の䦐値 濃度である $196 \mu \mathrm{g} / \mathrm{mL}$ 以下と $391 \mu \mathrm{g} / \mathrm{mL}$ 以上の閾值濃 度別に対象を分割し，それぞれの児で治療前後の閾値 濃度の変化を検討した。

気道過敏性の検討は, 保護者の承諾のもとに, メサ コリンを用いて日本アレルギー学会の標準法に準じて おこない（最大メサコリン濃度 $25,000 \mu \mathrm{g} / \mathrm{mL}{ }^{2}{ }^{2)} ， 1$ 秒 量 $\left(\mathrm{FEV}_{1.0}\right)$ がメサコリン吸入負荷前より $20 \%$ 以上減 少したメサコリン濃度を過敏性闇值（PC20）とした。

肺機能検査は, チェスト社製のチェストグラフ HI701 用いて測定した.
結果の比較は, 各薬剤使用前後のPC20の単純な比較, 薬剂使用前後で PC20が 8 倍以上の改善をみた者とみ なかった者の人数の比較, 薬剂使用後に気道過敏性を 軽度に残すのみとなったことを示すPC20である 5,000 $\mu \mathrm{g} / \mathrm{mL}$ 以上 (今回の検討では $6,250 \mu \mathrm{g} / \mathrm{mL}$ 以上) となっ た者とならなかった者の人数の比較で行い, 統計的検 討にはWilcoxon sign rank test, Mann Whitnney U検定, $\chi^{2}$ 乗検定, Fisherの直接確率計算法を用いた。

\section{結果}

\section{（検討 1)}

図1(a)にフルチカゾン吸入前後の, 図1(b)にプラン ルカスト内服前後の $\mathrm{PC} 20$ の変化を示した.いずれの薬 剂でも, 多くの症例でPC20の改善がみられ, 前後で 有意の差を観察した。

表 2 に, 2 回の検查間で PC 20 が 8 倍以上の改善を示 した児，示さなかった児の人数に対するフルチカゾン 吸入, プランルカストの効果を比較した結果を, 表 3 に治療後の $\mathrm{PC} 20$ が $6250 \mu \mathrm{g} / \mathrm{mL}$ 以上となった児となら なかった児の人数に対する両治療の効果を検討した結 果を示した. 治療後の PC20が $6250 \mu \mathrm{g} / \mathrm{mL}$ 以上となっ た児, ならなかった児の検討では, 両薬剤に差をみな かったが，8倍以上の PC20 の改善の有無の比較では, フルチカゾン吸入でプランルカスト使用より, より改 善傾向がみとめられた $(\mathrm{p}=0.0611)$.

表 1. 対象児の背景

\begin{tabular}{|c|c|c|}
\hline 使用抗炎症薬 & $\begin{array}{c}\text { フルチカゾン吸入 } \\
\text { (22名) }\end{array}$ & $\begin{array}{c}\text { プランルカスト内服 } \\
\text { (14名) }\end{array}$ \\
\hline 年齢 （歳） & $11.4 \pm 3.8$ & $10.0 \pm 4.0$ \\
\hline 発症年齢 （歲） & $3.5 \pm 2.4$ & $3.4 \pm 2.4$ \\
\hline 男：女（名） & $12: 10$ & $10: 4$ \\
\hline アトピー型 : 非アトピー型 （名） & $21: 1$ & $14: 0$ \\
\hline 軽症持続型：中等症持続型 （名） & $16: 6$ & $10: 4$ \\
\hline $\lg E(I U / m L)$ & $350.4 \pm 241.5$ & $315.6 \pm 261.2$ \\
\hline 治療開始前の\%FEV1.0（\%） & $92.1 \pm 5.4$ & $94.0 \pm 5.1$ \\
\hline
\end{tabular}




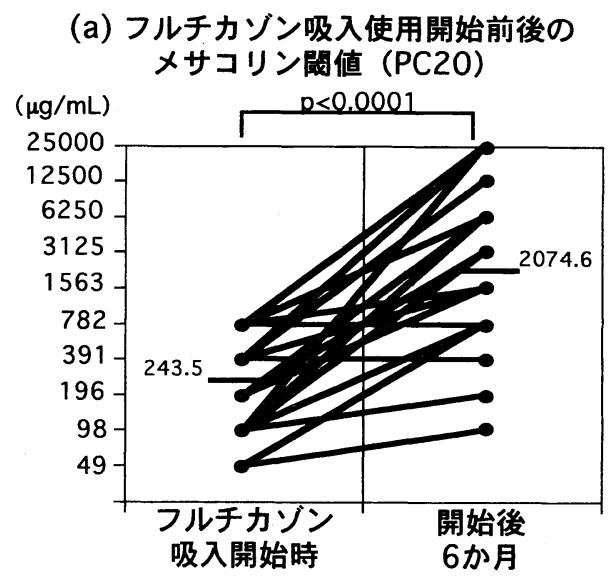

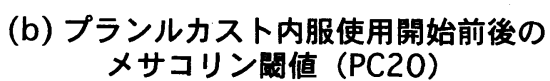

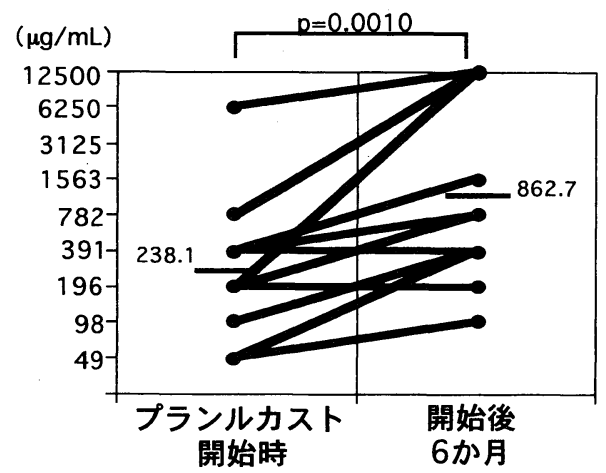

図 1. フルチカゾン吸入，プランルカスト使用開始前後のメサコリン閾值（PC20） （対象児全体）

表2.8倍以上の閾值濃度（PC20）の改善の有無の比較

\begin{tabular}{|c|c|c|}
\hline 使用抗炎症菜 & 改善あり（名） & 改善なし(名) \\
\hline フルチカソン吸入 & 13 & 9 \\
\hline プランルカスト内服 & 3 & 11 \\
\hline
\end{tabular}

表 3. 閾値（PC20）の $6250 \mu \mathrm{g} / \mathrm{mL}$ 以上への改善の有無の比較

\begin{tabular}{|c|c|c|}
\hline 使用抗炎症菜 & 改善あり（名） & 改善なし (名) \\
\hline フルチカソンン吸入 & 7 & 15 \\
\hline プランルカスト内服 & 3 & 11 \\
\hline
\end{tabular}

(NS)

\section{（検討 2)}

図 2 に治療開始前のPC20が $196 \mu \mathrm{g} / \mathrm{mL}$ 以下の児での， 図 3 に $391 \mu \mathrm{g} / \mathrm{mL}$ 以上の児での両薬剂治療前後での PC20の变化を示した．治療開始前PC20が高い者も低 い者も，両薬剤とも有意のPC20の改善を示した. 表 4,5に治療開始前のPC20が $196 \mu \mathrm{g} / \mathrm{mL}$ 以下の児での， 表 6,7 $7391 \mu \mathrm{g} / \mathrm{mL}$ 以上の児での, 2 回の検査間でPC20 が8倍以上の改善を示した児，示さなかった児の人数 に対する両治療の効果を比較した結果と，治療後の
$\mathrm{PC} 20$ が $6250 \mu \mathrm{g} / \mathrm{mL}$ 以上となった児とならなかった児 の人数に対する両治療の効果を検討した結果を示した。 治療開始前の PC20 が $196 \mu \mathrm{g} / \mathrm{mL}$ 以下の児では, 8 倍以 上のPC20の改善の有無の比較では, フルチカゾン吸入 でプランルカスト使用より有意の改善がみとめられた が $(\mathrm{p}=0.0238) ， 391 \mu \mathrm{gmL}$ 以上の児では差をみなかっ た。治療後の $\mathrm{PC} 20$ が $6250 \mu \mathrm{g} / \mathrm{mL}$ 以上となった児とな らなかった児の人数に対する両治療の効果の検討では, いずれの検討でも差を観察しなかった。 
(a) フルチカソン吸入使用開始前後の

メサコリン閾值 (PC20)

(治療開始前闘値 $196 \mu \mathrm{g} / \mathrm{mL}$ 以下の児11名)

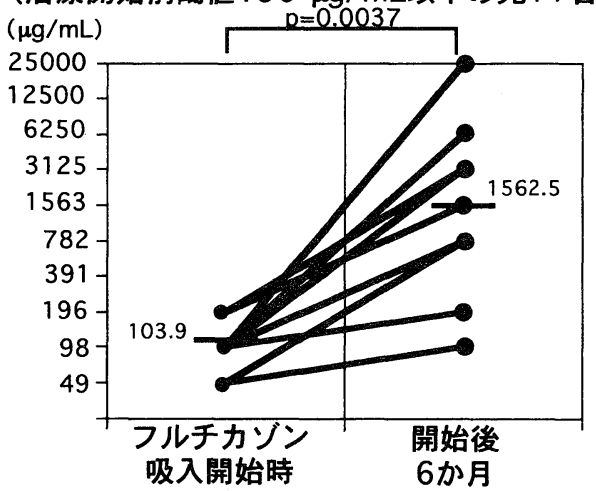

(b) プランルカスト内服使用開始前後の メサコリン閏值 (PC20)

（治療開始前闑值196 $\mu \mathrm{g} / \mathrm{mL}$ 以下の児8名）

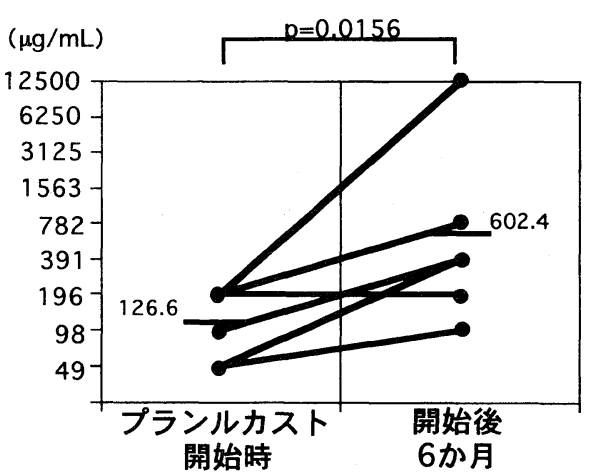

図2. フルチカゾン吸入，プランルカスト使用開始前後のメサコリン閾值（PC20） （治療開始前閾値 $196 \mu \mathrm{g} / \mathrm{mL}$ 以下の児）

(a) フルチカソン吸入使用開始前後の メサコリン闘値 (PC20)

（治療開始前䦚値391 $\mu \mathrm{g} / \mathrm{mL}$ 以上の児11名）

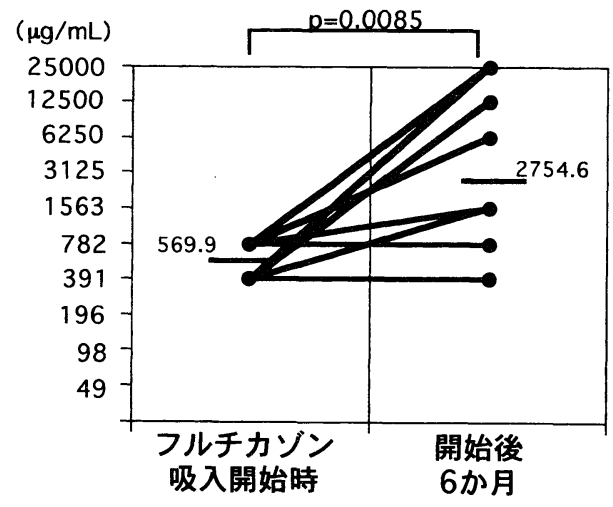

(b) プランルカスト内服使用開始前後の メサコリン閵値 (PC20)

（治療開始前䦚值391 $\mu \mathrm{g} / \mathrm{mL}$ 以上の児6名）

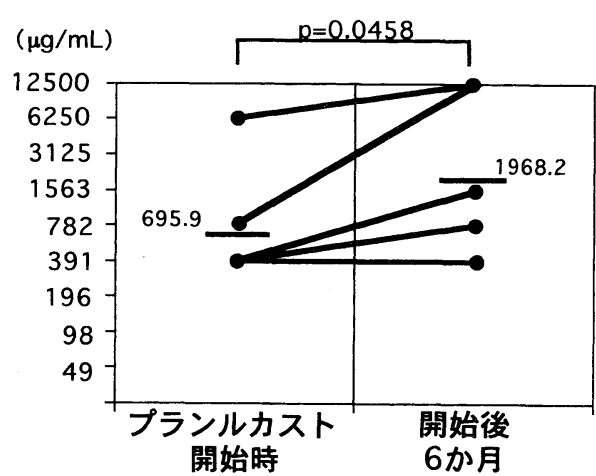

図 3. フルチカゾン吸入，プランルカスト使用開始前後のメサコリン閾値（PC20） (治療開始前闒値 $391 \mu \mathrm{g} / \mathrm{mL}$ 以上の児) 
表 4. 8 倍以上の闒値濃度（PC20）の改善の有無の比較 （治療開始前 PC20 $196 \mu \mathrm{g} / \mathrm{mL}$ 以下の児）

\begin{tabular}{|c|c|c|}
\hline 使用抗炎症菜 & 改善あり (名) & 改善なし (名) \\
\hline フルチカソンン吸入 & 9 & 2 \\
\hline プランルカスト内服 & 2 & 6 \\
\hline
\end{tabular}

表 5. 闒値（PC20）の $6250 \mu \mathrm{g} / \mathrm{mL}$ 以上への改善の有無の比較 （治療開始前 PC20 $196 \mu \mathrm{g} / \mathrm{mL}$ 以下の児）

\begin{tabular}{|c|c|c|}
\hline 使用抗炎症菜 & 改善あり (名) & 改善なし (名) \\
\hline フルチカソン吸入 & 3 & 8 \\
\hline プランルカスト内服 & 1 & 7 \\
\hline
\end{tabular}

表 6. 8 倍以上の閾値濃度（PC20）の改善の有無の比較 （治療開始前 PC20 $391 \mu \mathrm{g} / \mathrm{mL}$ 以上の児）

\begin{tabular}{|c|c|c|}
\hline 使用抗炎症薬 & 改善あり（名） & 改善なし(名) \\
\hline フルチカソン吸入 & 4 & 7 \\
\hline プランルカスト内服 & 1 & 5 \\
\hline
\end{tabular}

表 7. 閾値（PC20）の $6250 \mu \mathrm{g} / \mathrm{mL}$ 以上への改善の有無の比較 （治療開始前PC20 $391 \mu \mathrm{g} / \mathrm{mL}$ 以上の児）

\begin{tabular}{|c|c|c|}
\hline 使用抗炎症薬 & 改善あり(名) & 改善なし (名) \\
\hline フルチカゾン吸入 & 4 & 7 \\
\hline プランルカスト内服 & 2 & 4 \\
\hline
\end{tabular}




\section{考案}

今回の我々の結果から，軽症持続型から中等症持続 型の喘息児では，(1)半年程度の発作の抑制でも，抗炎 症薬としてフルチカゾン吸入, プランルカスト使用で, テオフィリン徐放薬の併用効果もあるかも知れないが, メサコリンに対する気道の過敏性閾值が有意の改善を 示すこと, (2)半年程度の使用および症状安定でも, フ ルチカゾン吸入はプランルカストより気道過敏性をよ り改善する傾向があり，治療開始前の過敏性閾值が低 い者ほどその可能性が高いが，治療開始前の過敏性閾 值が高い者では差をみないこと, (3)軽度の気道過敏性 を残すのみとなったことを示す，メサコリンの過敏性 閾值濃度である $5,000 \mu \mathrm{g} / \mathrm{mL}$ 以上（我々の検討では 6 , $250 \mu \mathrm{g} / \mathrm{mL}$ 以上） 八の改善の有無別の比較では，半年 程度の使用では，両薬剤の効果に差をみないことが示 された。

近年，喘息に対する薬物療法の進歩がみられ，特に， ステロイド吸入薬や，ロイコトリエン拮抗薬の使用開 始から，本邦においてもその使用と喘息による死亡率 の減少との関係が示唆されるようにまでなってきた ${ }^{3)}$. 小児においても，GINAガイドライン ${ }^{4)}$ ，小児気管支喘 息治療管理ガイドライン $2002^{1)}$ 等のガイドラインでこ れらの薬剂の長期管理薬としての使用が取り上げられ, 日常の喘息管理に用いられてきた．ステロイド吸入薬 やロイコトリエン拮抗薬の薬効や肺機能に関する効果 に関しては，その開発時から各種の報告がみられるが， 小児に関して今回我々が対象とした様な軽症ないし中 等症持続型の喘息に対する両薬剤の効果の比較につい ての報告は多くない，そのため成人での検討，中等症 以上の喘息での検討も含めてロイコトリエン拮抗薬, ステロイド吸入薬の効果を大まかにまとめると, 以下 の様に考えられる.

(1) ロイコトリエン拮抗薬とステロイド吸入薬をコン トローラーとして直接比較した検討では，ステロイ ド吸入薬がより有効であるとの報告がほとんどであ るが，軽症持続型の成人喘息で肺機能 $\left(\mathrm{FEV}_{1.0}\right)$ 以 外の発作回数, $\beta_{2}$ 刺激薬の使用量, 臨床症状では差 をみないとの報告 ${ }^{5)}$ ，小児も含んだ長期（37 週）の 比較で臨床的に両者ともほぼ同様に有用との報告も みられ ${ }^{6)}$, 両者の軽症患者へのコントローラーとし ての有効性が示唆されている.

(2)ステロイド吸入薬とロイコトリエン拮抗薬の併用で は，低用量のステロイド吸入薬で症状安定しない者
にロイコトリエン拮抗薬を併用する方が，ステロイ ド吸入薬の使用量増量より有効であり，また，高用 量ステロイド吸入薬使用者での併用では，ステロイ ド吸入薬の減量が図りうる (add-on 効果) ${ }^{7,8)}$.

(3)ロイコトリエン拮抗薬は, 軽症から中等症の小児へ 投与して有効であり，ロイコトリエン拮抗薬開始前 にステロイド吸入薬を使用している者に併用しても 有効であることから， ステロイド吸入薬使用で十分 にコントロールされていない児にも使用しうる ${ }^{9)}$.

(4)気道過敏性に関しては, 両薬剤とも使用開始後の改 善を示す報告が多い10,11). 両薬剤の気道過敏性に対す る効果の直接比較についての検討では, Riccioni ら ${ }^{11)}$ は，軽症の喘息児を対象とし，ブデソニド吸入単独， ザフィルカスト単独, ないし両者併用のいずれでも， PD20の改善がみられ, 各薬剤間にその改善度に有意 差がみられるものの, 軽症児に対する投薬コンプラ イアンスの良いロイコトリエン拮抗薬の気道過敏性 への効果の可能性と両薬剂の併用の効果を示唆して いる.

今回の我々の検討は, 治療により発作の消失した, 比較的少数の軽症持続型，中等症持続型症例を対象と したものではあるが，その結果から，どちらかといえ ば症状の軽い児が中心となる治療開始前の気道過敏性 の低い児に関しては，両薬剤の過敏性閾值に対する効 果がほぼ同等であるのに対し，重症度がより高いと思 われる過敏性閾值の前值が低い者ではステロイド吸入 薬の有効性が高いことが示された.この点は, 前記の これまでの報告にみられる, 軽症の喘息では, 両薬剤 ともほぼ同等の臨床効果がみられる場合もあるが, 軽 症持続型以上の者の肺機能, 気道過敏性に関しては, ステロイド吸入薬の方がロイコトリエン拮抗薬より改 善度が高いという，両薬剤の喘息患者に対する効果の 検討結果を支持する所見とも考えられた。

以上, 我々の今回の検討は, 軽症持続型, 中等症持 続型の喘息児を対象とし，抗炎症薬の6か月程度の治 療, 発作抑制の気道過敏性に対する効果をみたもので あったが,さらに, 対象児の発作抑制状況の判定にピー クフロー值を用いた場合, 検討薬剤を今回以上の長期 間使用し発作抑制を継続した場合，検討薬剤を各種併 用した場合，ステロイド吸入薬の使用量別に比較した 場合等, 各種の検討が引き続き必要と考えられた。 


\section{参考文献}

1）古庄巻史，西間三馨監修．小児気管支喘息治療管 理ガイドライン 2002. 東京: 協和企画通信, 2002.

2 ）牧野荘平, 小林節雄, 宮本昭正, 信太隆夫, 高橋 昭三, 可部順三郎, 中島重徳. 気管支喘息および 過敏性肺臟炎における吸入試験の標準法. アレル ギー $1982 ; 31: 1074-76$.

3 ) Suissa S, Ernst P. Use of anti-inflammatory therapy and asthma mortality in Japan. Eur Respir J. 2003 ; 21 : 101-4.

4) Global Initiative for Asthma. Establish medication plans for long-term asthma management in infants and children. Global strategy for asthma management and prevention. NIHB/WHO Workshop Report. NIH Publication No 02-3659. Bethesda, MD: National Institute of Health, 119-132, 2002.5.

5) Malmstrom K, Rodriguez-Gomez G, Guerra J, Villaran C, Pineiro A, Wei LX, Seidenberg BC, Reiss TF. Oral montelukast, Inhaled beclomethasone, and placebo for chronic asthma. a randamized, controlled trial. Ann Intern Med 1999; 130: 487-495.

6) Williams B, Noonan G, Reiss TF, Knorr B, Guerra J, White R, Matz J. Long-term asthma control with oral montelukast and inhaled beclomethasone for adults and children 6 years and older. Clin Exp
Allergy. 2001; 31: 845-854.

7 ) Laviolette M, Malmstrom K, Lu S, Chervinsky P, Pujet JC, Peszek I, Zhang J, Reiss TF. Montelukast added to inhaled beclomethasone in treatment of asthma. Am J Respir Crit Care Med 1999; 160: 1862-1868.

8 ) Lofdahl C-G, Reiss TF, Leff JA, Israel E, Noonan MJ, Finn AF, Seidenberg BC, Capizzi T, Kundu S, Godard P. Randomized placebo controlled trial of effect of a leukotriene receptor antagonist, montelukast on tapering inhaled corticosteroids in asthmatic patients. BMJ 1999; 319: 87-90.

9) Knorr B, Matz J, Bernstein JA, Nguyen H, Seidenberg BC, Reiss TF, Becker A. Montelukast for chronic asthma in 6- to 14-year-old children: a randomized, double-blind trial. JAMA 1998; 279: 1181-1188.

10) The childhood asthma management program research group. Long-term effects o budesonide or nedocromil in children with asthma. N Engl J Med 2000; 343: 1054-63.

11) Riccioni G, Castronuovo M, De Benedictis M, Pacepalitti V, Di Gioacchino M, Della Vecchia R, Schiavone C, Sensi S, Guagnano MT. Zafirlukast versus budesonide on bronchial reactivity in subjects with mild-persistent asthma. Int $\mathrm{J}$ Immunopathol Pharmacol 2001; 14: 87-92. 


\title{
THE EFFECTS OF ANTI-INFLAMMATORY DRUGS \\ (INHALED FLUTICASONE PROPIONATE AND PRANLUKAST HYDRATE) \\ ON BRONCHIAL REACTIVITIES IN BRONCHIAL ASTHMA CHILDREN.
}

\author{
Hiroayasu Okahata, Tetsurou Tsuji, Kazunari Daikoku \\ Department of Pediatrics, Otake National Hospital
}

The effects of inhaled fluticasone and pranlukast on bronchial reactivities in 36 mild persistent or moderate persistnet asthma patients aged 7-15 years (22patients treated with inhaled fluticasone and 14 patients with pranlukast) were studied. All patients were treated with those drugs for more than 6 months and showed no asthmatic attacks for more than 5 months. Those patients were also treated only with sustained released theophylline and dosage of inhaled fluticasone, pranlukast and theophylline on each patients were not changed. At the biginning of antiinflammatory drug treatments and at 6 months after the biginning of the treatments, bronchial reactivities (provocation concentration, PC20) were studied with methacholine. Geometric averages of PC20 in patients who treated with inhaled fluticasone were $243.5 \mu \mathrm{g} / \mathrm{mL}$ at the biginning of the treatment and $2074.6 \mu \mathrm{g} / \mathrm{mL}$ after 6 months treatments, whereas those of PC20 in patients treated with pranlukast were $238.1 \mu \mathrm{g} / \mathrm{mL}$ and $862.7 \mu \mathrm{g} / \mathrm{mL}$, respectively. Both treatments showed statistically significant changes in PC20.

Between before and after treatments, PC20 in 13 patients in 22 patients treated with inhaled fluticasone increased more than 8 times, whereas those in 3 patients in 14 patients treated with planlukast showed more than 8 times increments $(\mathrm{p}=0.0611)$. Among 19 patients who showed high bronchial reactivities (PC20 $196 \mu \mathrm{g} / \mathrm{mL})$ before those drugs treatments, their differences were significant $(\mathrm{p}=0.0238)$.

These results suggested that influences of treatments with inhaled fluticasone or pranlukast on bronchial reactivities in asthma children who did not suffer from asthmatic attacks for more than 5 months after treatments were different, and inhaled fluticasone showed stronger influences in asthma patients' bronchial reactivities than pranlukast. 